\title{
Long-term geochemical assessment of groundwater in a hard- rock aquifer system
}

\section{Amina Khatun and Madan Kumar Jha}

See end of the Paper for authors' affiliation

Correspondence to :

Amina Khatun

Department of Agricultural and

Food Engineering, Indian

Institute of Technology,

Kharagpur (W.B.) India

Email: aminakhatun9286@

gmail.com

Received : 18.08.2019; Revised : 01.09.2019; Accepted : 22.09 .2019

ABSTRACT : Groundwater is one of the most vital natural resource supporting the survival of human civilization. Lowering of groundwater levels accompanied by deteriorating groundwater quality worldwide has created a serious concern about sustainability of water supply in the $21^{\text {st }}$ century. Rapid urbanization and unplanned management of day-to-day activities has led to the release of harmful substances to groundwater resources depleting the qualitative aspect of groundwater. In this study, the concentration of 13 groundwater-quality parameters for the confined aquifer of 14 blocks in the study area located in South India were analyzed critically using premonsoon and post-monsoon groundwater-quality data for 34 years. Both statistical and graphical methods were employed to analyze the spatial and temporal variability in the concentration of groundwater-quality parameters. Two groundwater quality diagrams (Piper diagram and Schoeller diagram) were prepared for the geochemical classification of groundwater of the aquifer. Groundwater quality was also analyzed for irrigation suitability. The results indicated statistically significant long-term variation in the concentration of $\mathrm{pH}, \mathrm{F}^{-}, \mathrm{Ca}^{2+}, \mathrm{Mg}^{2+}$ and $\mathrm{K}^{+}$. Also, a majority of the groundwater-quality parameters' concentration was found to be spatially significant. Piper diagram revealed that groundwater in the study area is mainly of $\mathrm{Na}-\mathrm{Cl}^{-}$and $\mathrm{Ca}-\mathrm{Mg}_{-} \mathrm{SO}_{4}{ }^{2-}$ types with $\mathrm{Na}^{+}$, and $\mathrm{Cl}^{-}$and $\mathrm{HCO}_{3}^{-}$as dominant cation and anions, respectively. It was found that the concentration of Total Dissolved Solids and Total Hardness in the confined aquifer exceed their maximum permissible limits for drinking water. The US Salinity Laboratory diagram revealed high salinity in the groundwater with low sodium hazard. In terms of magnesium hazard, groundwater of the entire area is unsuitable for irrigation.

- KEY WORDS : Groundwater quality, Geochemical classification, Spatio-temporal variation, Hydrochemical facies

- HOW TO CITE THIS PAPER : Khatun, Amina and Jha, Madan Kumar (2019). Long-term geochemical assessment of groundwater in a hard-rock aquifer system. Internat. J. Agric. Engg., 12(2) : 264-285, DOI: 10.15740/HAS/IJAE/12.2/264-285. Copyright@ 2019: Hind AgriHorticultural Society. 